\title{
Professor Deane K. Smith and the journal Powder Diffraction
}

The December issue of the journal Powder Diffraction is dedicated in memory of Professor's Deane K. Smith for his outstanding services as the journal's first Editor-in-Chief for 13 years (1986-1999) and the Editor for Reviews and Reprints for three years (1999-2001). Professor Smith and the first crystal structure of uranophane published by him in 1957 are featured on the cover. An obituary on Professor Smith prepared by Drs. C. R. Hubbard, R. Jenkins and R. L. Snyder is given below. Two representative papers published previously by Professor Smith in Advances in X-ray analysis (namely, Clay mineral analysis by automated powder diffraction analysis using the whole diffraction pattern and Particle statistics and whole-pattern methods in quantitative X-ray powder diffraction analysis) are reprinted in this issue. A new paper, presumably the last paper prepared by Professor Smith (entitled Review of questionnaire to AIHA accredited laboratories for the analysis of silica) is also published in this issue. Professor Smith was not only an excellent editor, but also a proficient author and an outstanding researcher. We all will miss him.

\section{Obituary-Deane K. Smith}

Deane K. Smith passed away on September 7th at his home in State College, PA. Deane was born Nov. 8, 1930, in Berkeley, California. He was a son of the late Deane K. Sr. and Anna Virginia Long Smith. In July, 1953, he married Patricia Ann Lawrence, who survives him at home. In addition to his wife, Deane is survived by three daughters, Paula Lynn Smith of Seattle, Jeanette D. Metcalf of Chesterland, Ohio, and Sharon R. Stanford of Colbran, Colo.; two sons, Kingsley L. of Madison, Wis., and Dana E. of State College; and nine grandchildren.

In 1952, Deane graduated from the California Institute of Technology with a bachelor's degree in geology, and in 1956 he graduated from the University of Minnesota with a doctorate in geology. From 1956-60, he was a research associate of the Portland Cement Association Fellowship at the National Bureau of Standards in Washington, D.C. During the 1960s, he worked as a chemist and diffractionist in the Inorganic Materials Division of the Lawrence Radiation Laboratory in California and later as assistant section leader of the lab's Properties of Materials section. In 1968, he joined Penn State University's Department of Geosciences as an associate professor and became professor in 1971. Following 27 years of teaching and research, he became professor emeritus of mineralogy at Penn State. During his career, he published many papers and won numerous awards, including the C. S. Barrett Award in Diffraction Analysis for lifetime achievement in X-ray diffraction. A newly discovered mineral, Deanesmithite, was named after him. As proprietor of the Gem Dugout, he became a worldwide source for specialized X-ray diffraction needs. Deane was a Fellow of the Geological Society of America and the Mineralogical Society of America and was elected to the Commission on
Powder Diffraction of the International Union of Crystallography for 1993-96.

Deane's long career impacted most areas of geology and powder diffraction analysis. He performed some early high temperature experiments while at NBS as well as impacting the understanding of one of the most complex phase assemblages in materials science: Portland Cement. At Lawrence Livermore Labs, Deane developed the first version of his powder pattern calculating program which over time has become the accepted standard for such computations. The first published major work using this early POWD program was not just a few example patterns but instead a full booklength compendium of silicate mineral patterns written with Iris Borg and published by the Geological Society of America. Many people collaborated with Deane on the development of POWD over the years with his son Kingsley being one of the most recent contributors to the development of the MDI PC version. During this time Deane took one of us $\left(^{*}\right)$ into his group as a summer intern where I learned about X-ray characterization, the value of reference data which was a major theme in Deane's subsequent four decades. In 1976 I had the opportunity to collaborate with Deane on the rationalization of the scale factor from calculated patterns for quantitative analysis (now known as RIR) and relating it to the experimentally determined I/Ic. We followed with many years of testing and refining POWD. Deane continued the development of quantitative analysis methods with the technique for whole pattern quantitative analysis developed initially for clays. Deane was the prime driving force of this development. The foundations in calcu- 
lation of reference powder patterns and in whole pattern analysis proved to be a major lighthouse towards the development of modern analytical methods of X-ray analysis. In addition to these widely used methods, Deane published the well-known book on Specimen Preparation with Ron Jenkins and Vic Buhrke, as well as a recent book with Frank Chung. Deane's contributions to the literature and our craft will live long and affect generations to come.

Deane was a long time member of the ICDD, Distinguished Fellow (1995), 16-year board member, and Chairman of the Board from 1978-1982 and 1986-1990. Throughout this time, Deane was a major contributor to the Minerals Subcommittee and participated in extensive editing of the new mineral patterns of the Powder Diffraction File. Deane co-founded and became the first Editor-in-Chief for the journal, Powder Diffraction, a position that he held for thirteen years (1986-1999). Deane also served as a primary instructor at the ICDD's X-ray diffraction clinics since 1991. In his capacity as a member of the Organizing Committee of the Denver X-ray Conference, Deane also contributed his expertise in developing dynamic conference programs for the education of the XRD and XRF communities.

I (**) had the opportunity to travel many times with Deane for international workshops and business meetings. Deane loved to eat-his all-time favorite, rack of lamb! I recall that during Deane's second term as ICDD Board Chairman, frequent meetings with headquarters staff were necessary, especially with the birth of the new Powder Diffraction Journal. Good hotels in the area were few and far between, so Deane would often stay at my home. At that time we owned a beautiful 170 pound Chesapeake Bay $\operatorname{Re}$ triever called Lenny. Deane also loved dogs. With Deane an Lenny it was love at first sight! More recently Deane ac quired three superb Collies. He always carried around th latest dog pictures and insisted that all in the immediate vi cinity examine the pictures. It was at the time of the birth o the new Journal that Deane was diagnosed with breast can cer. The next 16 years were to be an ongoing battle with th disease. A special bond developed between Deane and $m$ over the past decade as we each faced the ravages of cancer We discussed our treatments, side effects, shortcomings o the medical profession, and were a valuable support for eacl other. Humans are a gregarious strain and we all need clos interpersonal relationships to help us through difficult times About 400 years ago, the British poet and cleric, John Donn (1572-1631) wrote a poem, part of which reads as follows

No man is an island entire unto itself, every man is par of the Continent, a part of the main. Any man's death dimin ishes me because I am involved in mankind, and therefor never send to know for whom the bell tolls, it tolls for thee

Others will come forward to take Deane's place, but the' can never replace him. Deane was a unique combination o teacher, researcher, organizer, director, family man and do: lover. He was a good friend. His passing diminishes us al] We will miss him. 